$\stackrel{\circ}{\text { III }}$

$\|$

\title{
DOŚWIADCZANIE WDOWIEŃSTWA A NOWE ZWIAZZKI ROMANTYCZNE W OKRESIE PÓŹNEJ DOROSŁOŚCI
}

\begin{abstract}
Klaudia Rodziejczak, Doświadczanie wdowieństwa a nowe zwiqzki romantyczne w okresie późnej dorosłości [The Experience of Widowhood and New Late-life Romantic Relationships] edited by L. Bakiera, M. Obrębska „„"Zzłowiek i Społeczeństwo” vol. LI: Blisko czy na dystans? Psychologiczne aspekty relacji międzyludzkich [Closely or distantly? The psychological aspects of interpersonal relations], Poznań 2021, pp. 119-132, Adam Mickiewicz University. ISSN 0239-3271, https://doi. org/10.14746/cis.2021.51.6.
\end{abstract}

The current population of widows and widowers in Poland is over $3.1 \mathrm{mln}$, whereof the vast majority is over 60 years old. Death of long-life partner is one of the most stressful events in an individual's life and it may affect their physical and mental condition. At the same time acceptance of spouse's death and successful adaptation to widowhood are the developmental tasks of late adulthood phase, which may provide to personal growth. A widowed person can decide if they desire to engage new romantic relationship. Research shows that starting a new relationship is motivated by various factors: psychological (e.g. spouse idealization, anxiety), biological (e.g. age, health), and external factors (e.g. socioeconomic situation). New late-life romantic relationships differ from previous stages of life - we can observe changes in: relationship goals, dynamic of the relationship and together activities, although seniors experience passionate love the same way that younger generations do.

Keywords: widowhood, late adulthood, romantic relationships, mourning, desire to have a partner

Klaudia Rodziejczak, Uniwersytet im. Adama Mickiewicza w Poznaniu, Wydział Psychologii i Kognitywistyki, Szkoła Doktorska, ul. Szamarzewskiego 89AB, 60-568 Poznań, e-mail: klarod@ amu.edu.pl, ORCID: https://orcid.org/0000-0003-0005-5741. 


\section{Wprowadzenie}

W Polsce żyje 3,1 mln owdowiałych osób, przy czym 2,6 mln z nich to kobiety, co oznacza, że liczba wdów jest prawie sześciokrotnie wyższa niż liczba wdowców (Stańczak i Marzec, 2013). Wraz z postępującym zjawiskiem starzenia się społeczeństwa w Polsce zwiększać się będzie udział osób w okresie późnej dorosłości w ogólnej populacji - do 2030 r. przewiduje się, że liczba osób w wieku emerytalnym przekroczy 9,6 mln - nastąpi wzrost o ok. 62\% w porównaniu z rokiem 2005 (Kleiber, 2008). Tym samym będzie można zaobserwować również wzrost liczby wdów i wdowców w okresie późnej dorosłości.

Śmierć współmałżonka jest wydarzeniem rozpoczynającym nowy etap w życiu drugiego partnera. Wdowy i wdowcy zmagają się z adaptacją do nowej sytuacji, a po odbyciu żałoby podejmują decyzję, czy chcą poszukiwać kolejnego partnera życiowego. Opierając się na literaturze przedmiotu, a także na doświadczeniach własnych w kontakcie z seniorami oraz osobami koordynującymi lokalne inicjatywy senioralne, można stwierdzić, że temat ten jest ważny dla owdowiałych osób. Biorąc pod uwagę powyższe dane, tematyka związków romantycznych wdów i wdowców po 60. roku życia wydaje się obszarem godnym uwagi z perspektywy psychologicznej, zwłaszcza że problematyka ponownych relacji romantycznych wdów i wdowców jest stosunkowo rzadko poruszanym tematem w polskiej literaturze (Kaleta i Jaśkiewicz, 2007; Kleszcz-Szczyrba, 2012; Niewiedział, 2014).

Celem prezentowanej pracy jest przedstawienie sytuacji psychologicznej osób owdowiałych w okresie późnej dorosłości w kontekście wchodzenia w ponowne związki romantyczne, a ponadto próba scharakteryzowania funkcjonowania tego typu związków oraz uwarunkowań psychologicznych i socjodemograficznych, które oddziałują na podejmowane przez nich decyzje o chęci posiadania partnera życiowego.

\section{Wdowieństwo i ponowne związki w perspektywie demograficznej}

Ostatni przeprowadzony w Polsce Narodowy Spis Powszechny miał miejsce w 2011 r. Stwierdzono wówczas, że w kraju żyje 3,1 mln wdów i wdowców. Odnotowano znaczną przewagę kobiet wśród owdowiałych osób - stanowiły 
one ok. 84\% całej grupy. Powstaje pytanie, jakie są powody tej dysproporcji między wdowami i wdowcami. Przyczynę mogą stanowić następujące czynniki: ogólna dłuższa średnia życia kobiet $(81,9)$, która o osiem lat przewyższa średnią długość życia mężczyzn $(73,9)$, oraz powiązane z tym zjawisko określane jako „nadumieralność mężczyzn” (większa liczba zgonów w porównaniu z kobietami w każdym wieku). Dodatkowo warto wspomnieć o różnicy wieku w związku - z reguły to mężczyzna jest nieznacznie starszy od kobiety. Wymienione zjawiska prowadzą do zaobserwowanej przewagi liczby wdów we wszystkich grupach wiekowych, co przedstawione zostało w tabeli 1.

Tabela 1. Udział procentowy wdów i wdowców w społeczeństwie w wieku od 60 do ponad 100 lat

\begin{tabular}{|c|c|c|}
\hline Wiek & Mężczyźni & Kobiety \\
\hline $60-64$ & 5,4 & 23,2 \\
\hline $65-69$ & 7,9 & 35,3 \\
\hline $70-74$ & 11,9 & 49,2 \\
\hline $75-79$ & 18,0 & 63,1 \\
\hline $80-84$ & 28,0 & 75,7 \\
\hline $85-89$ & 41,6 & 84,6 \\
\hline $90-94$ & 55,5 & 89,4 \\
\hline $95-99$ & 67,4 & 91,6 \\
\hline $100+$ & 60,0 & 90,9 \\
\hline
\end{tabular}

Źródło: opracowanie własne na podstawie Szukalski, 2016: 2.

Dane zawarte w tabeli 1 wskazują, że już po 75. roku życia większość kobiet $(63,1 \%)$ jest wdowami, podczas gdy mężczyźni w przeważającej części $(55,5 \%)$ stają się wdowcami dopiero po 90. roku życia (Szukalski, 2016). Ta dysproporcja ma swoje konsekwencje, jeśli chodzi o poszukiwania partnera przez wdowy - słabe zróżnicowanie na „rynku wdowców” sprawia, że część kobiet, pomimo istniejącego pragnienia posiadania partnera, nie jest w stanie wejść w nowy związek (Szukalski, 2015). Ponadto większa dostępność wdów ma wpływ także na prowadzone w dziedzinie psychologii badania - istnieje niewiele prac empirycznych skoncentrowanych na owdowiałych mężczyznach, co pozostawia spore pole do działania dla badaczy w przyszłości. 
Dane demograficzne umożliwiają określenie udziału osób owdowiałych wśród zawieranych w Polsce małżeństw powtórnych, co nie daje pełnego obrazu częstotliwości wchodzenia w ponowne związki wdów i wdowców, gdyż w zestawieniach nie są brane pod uwagę związki nieformalne. Małżeństwa powtórne można zdefiniować jako „nowo rejestrowane związki małżeńskie, w których przynajmniej jedno z nowożeńców posiada już jakieś doświadczenia małżeńskie” (Szukalski, 2015). W odniesieniu do osób owdowiałych małżeństwo powtórne będzie dotyczyło par złożonych z: dwóch osób owdowiałych, osoby owdowiałej i osoby rozwiedzionej lub osoby owdowiałej i panny/kawalera.

W ostatnich dziesięcioleciach zauważalny jest spadek liczby małżeństw powtórnych zawieranych przez osoby owdowiałe. Podczas gdy w okresie międzywojennym najczęściej legalizowane powtórne związki dotyczyły: panny i wdowca (do 57\%), kawalera i wdowy (do 21\%) oraz wdowy i wdowca (do 20\%), to współcześnie wymienione typy stanowią do 10\% wszystkich powtórnie zawieranych małżeństw. Tendencja ta wyjaśniana jest redukcją umieralności (ogólnie wydłużający się okres życia ludzi) oraz wzrostem liczby związków nieformalnych także wśród osób w okresie późnej dorosłości (Szukalski, 2013). Dodatkowo wart uwagi jest fakt, że więcej wdowców niż wdów zawiera powtórne małżeństwo, co potwierdza wspomnianą wcześniej trudność wdów w znalezieniu potencjalnego partnera życiowego ze względu na ograniczoną liczbę owdowiałych mężczyzn (Szukalski, 2015).

\section{Doświadczenie wdowieństwa - szanse i zagrożenia rozwoju}

Śmierć współmałżonka jest z reguły wydarzeniem nieuniknionym. Wprawdzie śmierć partnera lub partnerki nie jest zjawiskiem zarezerwowanym wyłącznie dla okresu późnej dorosłości, lecz właśnie wówczas występuje najczęściej (Szukalski, 2013). Utrata partnera życiowego może być traktowana dwojako: z jednej strony jako silny stresor niosący za sobą wiele negatywnych konsekwencji, a z drugiej jako niemożliwe do uniknięcia wydarzenie mające znaczny wpływ na rozwój człowieka w okresie późnej dorosłości. Oba wymienione podejścia wydają się istotne w kontekście romantycznych związków wdów i wdowców, gdyż dopiero pomyślna adaptacja do wdowieństwa pozwala na podejmowanie prób wchodzenia w nowe związki (Casarett i in., 2001, za: Steuden, 2020). 
Niewątpliwie śmierć partnera życiowego może być traktowana jako silny stresor - Thomas H. Holmes i Richard H. Rahe (1967) śmierć współmałżonka określili jako najbardziej stresujące wydarzenie życiowe (100 pkt na 100 możliwych). Dla porównania śmierć innego bliskiego członka rodziny oceniona została na 63 punkty, zajmując 5. miejsce na liście za takimi wydarzeniami, jak: rozwód, separacja/rozstanie i pobyt w więzieniu. Badania wskazują, że u osób owdowiałych ryzyko zgonu wzrasta nawet o $48 \%$ (Sullivan i Fenelon, 2014), ponadto można zaobserwować wyższe nasilenie nastrojów depresyjnych oraz pogorszenie funkcjonowania w sferze społecznej w ciągu pierwszego roku wdowieństwa (Evenson i in., 2003). Adam Zych (2010) wskazuje, że poza osobami żyjącymi w pojedynkę, to właśnie osoby owdowiałe pozostają najbardziej narażone na osamotnienie, a Elżbieta Trafiałek (2003) opisuje zwiększone ryzyko izolacji społecznej u osób, które mają większe trudności z pogodzeniem się ze śmiercią partnera. Należy jednak pamiętać, że większość ludzi jest w stanie przystosować się do sytuacji wdowieństwa i życia w pojedynkę (Casarett i in., 2001, za: Steuden, 2020), mimo że dostarczane przez otoczenie wsparcie społeczne nie jest w stanie do końca zrekompensować braku bliskości ze zmarłym współmałżonkiem (Antonucci, 1994, za: Zettel i Rook, 2004).

Zgodnie z psychologią life-span człowiek rozwija się przez całe swoje życie (Straś-Romanowska, 2001). Badacze niejednokrotnie podejmowali próbę wyodrębnienia i szczegółowego opisania etapów w cyklu życia oraz towarzyszących im zadań rozwojowych. Można się odwołać do koncepcji klasyków psychologii rozwojowej, takich jak Robert Havighurst (1972) czy Daniel J. Levinson (1978). Zadania rozwojowe swoje źródła mają w dojrzewaniu organizmu, zmianach fizjologicznych, wymaganiach społecznych oraz wewnętrznych potrzebach i ideałach danej jednostki (Brzezińska i Trempała, 2003; Stalmach i Zawadzka, 2015). Dotyczą one zdolności, wiedzy i przekonań, które powinny zostać uzyskane przez osobę w określonym stadium, a ich realizacja oddziałuje na poczucie satysfakcji oraz powodzenie w wypełnianiu kolejnych zadań. Natomiast niepodjęcie się realizacji zadań rozwojowych może się wiązać z negatywnymi konsekwencjami psychologicznymi pod postacią wewnętrznego niepokoju i trudności z realizacją kolejnych zadań, a także z następstwami zewnętrznymi związanymi z dezaprobatą otoczenia (Przetacznik-Gierowska i Tyszkowa, 2006). W kontekście wdowieństwa Havighurst (1972) wskazuje zadanie: „pogodzenie się ze śmiercią współmałżonka(i)”, czego odpowiednikiem w teorii Levinsona (1978) jest: „przygotowanie się do straty bliskich osób”. Havighurst koncentruje się wyłącznie na utracie współmałżonka i rozwoju 
związanym z przystosowaniem się do życia w pojedynkę. Z kolei Levinson zwraca uwagę na to, że w okresie późnej dorosłości istnieje większe niż dotychczas ryzyko śmierci bliskich osób, nie tylko współmałżonka, co może skutkować zmniejszeniem się dotychczasowej grupy stanowiącej wsparcie dla jednostki.

Z wymienionymi zadaniami rozwojowymi wiąże się, wspomniana już wcześniej, adaptacja do wdowieństwa. Według badaczy żałoba po utracie partnera trwa średnio od 18 do 24 miesięcy (Kielar-Turska, 2002). W tym czasie większość osób jest w stanie pogodzić się ze śmiercią współmałżonka i osiągnąć równowagę psychiczną. Zwiększa się wówczas zaufanie do siebie, wzrasta także poczucie własnej wartości. Osoba owdowiała rozpoczyna nowy etap, niekiedy włączając do swojego życie nowe zainteresowania i formy zaangażowania (Tedeschi, Park i Calhoun, 1998).

\section{Charakterystyka związków romantycznych w późnej dorosłości}

Ze względu na tematykę artykułu autorka ograniczy się do scharakteryzowania relacji romantycznych w kontekście osób owdowiałych wchodzących w nowe związki romantyczne w okresie późnej dorosłości. Przyjęto definicję miłości romantycznej (ang. passionate love) skonstruowaną przez Elaine Hatfield i Williama Walstera (1978), która jest opisywana jako: „Intensywne pragnienie połączenia się, bycia jednością z drugą osobą; stan silnego pobudzenia fizjologicznego. Przy czym miłość odwzajemniona wiąże się z odczuciami spełnienia i ekstazy, a nieodwzajemnienie i separacja powoduje poczucie pustki, niepokoju i rozpaczy" (Hatfield i Walster, 1978: 9). Czy osoby w okresie późnej dorosłości mogą nawiązać nową relację opartą na takim „szczenięcym” uczuciu, kojarzonym powszechnie z okresem wczesnej dorosłości?

W społeczeństwie wciąż można się spotkać z negatywnymi stereotypami związanymi ze starością. Osoby po 60. roku życia są niekiedy infantylizowane, uważane za słabe, zależne od rodziny i pomocy społecznej; podkreśla się ich niepełnosprawności, zarówno fizyczne, jak i deficyty w funkcjach poznawczych (Steuden, 2020). Traktowane są jako osoby pozbawione atrakcyjności fizycznej i nieodczuwające popędu seksualnego (Grabowska, 2007). Negatywne postrzeganie seksualności seniorów i traktowanie ich jako, w pewnym sensie, osoby bezpłciowe, Robert Butler (2005) zakwalifikował jako jeden z przejawów ageizmu, który w wyjątkowo szkodliwy 
sposób oddziałuje na ogólną sytuację osób starszych. Jednakże coraz częściej przeprowadzane są badania, które opisują pozytywne aspekty okresu późnej dorosłości i podkreślają szanse na rozwój oraz satysfakcjonujące życie, także w sferze seksualnej (m.in. Bielan i Stanowska, 2014; Grabowska, 2007; Malta, 2013; Steuden, 2020).

Różnice w przeżywaniu miłości romantycznej w zależności od wieku badali Alvin Y. Wang i Ha T. Nguyen (2010). Zebrano 255-osobową grupę Amerykanów w wieku 14-80 lat, których zadaniem było wypełnienie skali Passionate Love Scale autorstwa Elaine Hatfield i Susan Sprecher (1986). Nie zaobserwowano istotnych różnic w przeżywaniu miłości pod względem behawioralnym i emocjonalnym, jednakże wystąpiły różnice w podskali dotyczącej aspektu poznawczego miłości. Wyniki badania sugerowały, że osoby w okresie późnej dorosłości odznaczały się większą dojrzałością, np. ich myśli z mniejszym natężeniem krążyły wokół partnera, co stanowiło charakterystyczny przejaw zakochania u adolescentów. Badania Wang i Nguyen (2010) dowodzą, że konstrukt miłości romantycznej, wbrew powszechnym opiniom i stereotypom, nie jest zarezerwowany wyłącznie dla adolescentów i młodych dorosłych - seniorzy mogą odczuwać miłość romantyczną z taką samą intensywnością.

W literaturze zarówno polskiej, jak i zagranicznej istnieje niewiele analiz dotyczących stosunku seniorów do randkowania oraz zachowań związanych z poszukiwaniem partnera. Badań jakościowych na ten temat podjęła się Sue Malta (2013). Przeprowadzone zostały wywiady z Australijczykami powyżej 60. roku życia na temat wchodzenia w nowe związki po rozwodzie lub śmierci partnera życiowego. Z punktu widzenia tego artykułu istotne wydają się wnioski dotyczące strategii wchodzenia w nowe związki. Zaobserwowano, że osobom, które w sposób przypadkowy i niezamierzony poznały swojego nowego partnera, towarzyszyło poczucie zaskoczenia i niedowierzania. Może to oznaczać, że część osób starszych zinternalizowała istniejące stereotypy i nie wierzyła, że w pewnym wieku wejście w nową romantyczną relację jest możliwe. Z kolei osoby, które z własnej inicjatywy, w sposób zaplanowany poszukiwały partnera (np. zamieszczając ogłoszenia na portalach randkowych), nie odczuwały zaskoczenia, gdy udało im się rozpocząć związek. Dodatkowo zaobserwowano, że rozwój tego typu związków jest bardzo dynamiczny i szybko dochodzi do zwiększenia się intymności w diadzie, co tłumaczy się pośpiechem wynikającym z poczucia, że nie warto tracić czasu, który pozostał do końca życia jednostki (Carstensen, 1992; za: Malta, 2013).

Warto zwrócić uwagę na to, że sytuacja seniorów, którzy tworzą nowe związki, różni się od sytuacji par w okresie wczesnej i średniej dorosłości. 
Dochodzi do zaburzenia podziału obowiązków na tradycyjnie męskie i kobiece (Coverman i Sheley, 1986; Malta, 2013). Najczęściej osoby te nie są już odpowiedzialne za wychowanie dzieci, są na emeryturze, spędzają więcej czasu w domu we własnym towarzystwie. W drobnych naprawach czy pracach domowych często pomagają im dzieci osoby owdowiałej lub fachowcy, gdyż seniorzy nie mogą ich wykonywać ze względu na pogarszającą się sprawność fizyczną (Szinovacz i Harpster, 1994). Biorąc pod uwagę zmiany życiowe w wymienionych powyżej obszarach, często dochodzi do nowego, mniej tradycyjnego podziału obowiązków między partnerami. Ponadto głównym celem związku staje się udzielanie sobie wzajemnego wsparcia emocjonalnego, społecznego i instrumentalnego (Carr, 2004).

Jak już wspomniano, liczba zawieranych ponownych małżeństw między osobami owdowiałymi spada na rzecz związków kohabitacyjnych. Towarzyszyć temu może trend nazywany LAT (ang. living apart together) polegający na pozostawaniu w niesformalizowanym bliskim związku, w którym partnerzy nie zamieszkują razem (Karlsson i Borrell, 2002). Osobne mieszkanie pozwala seniorom na zachowanie większej niezależności, oddzielenie życia rodzinnego (np. spotkania z dziećmi) od nowego związku. Dlatego najczęściej na taki rodzaj związku decydują się osoby, dla których ważne są własne nawyki i potrzeby. Osoby te chcą zachować autonomię, mieć przestrzeń dla siebie i swoich zainteresowań. Związki działające na zasadzie LAT charakteryzują się większą intymnością niż relacje oparte na samym randkowaniu, jednakże nie wymagają tak dużego zaangażowania jak związek małżeński z prowadzonym wspólnie gospodarstwem domowym. Korzyści ze związku koncentrują się wokół posiadania towarzystwa i otrzymywania wsparcia emocjonalnego, natomiast para nie musi dzielić między siebie obowiązków czy podejmować wspólnie decyzji dotyczących np. zarządzania majątkiem. Badania nad związkami typu LAT wskazują, że 36\% przebadanych par spotykało się prawie codziennie, 51\% co najmniej raz w tygodniu, a $12 \%$ przynajmniej raz w miesiącu. Obserwowano też zróżnicowanie pod względem wprowadzania partnera w swoją sieć kontaktów interpersonalnych - większość osób (66\%) znała zarówno rodzinę, jak i znajomych partnera, część osób zapoznawała partnera tylko ze znajomymi, ale zdarzało się również (7\% respondentów), że pary decydowały nie wprowadzać się wzajemnie w krąg swojej rodziny i znajomych. Dodatkowo na podstawie wyników badań można stwierdzić, że to kobiety częściej chcą zachować własną niezależność i proponują związek typu LAT (Karlsson i Borrell, 2005). Powodem tej zależności może być fakt, że wdowom wspólne mieszkanie z partnerem częściej kojarzy się z licznymi obowiązkami związanymi 
z prowadzeniem gospodarstwa domowego i byciem „opiekunką” dla partnera w czasie jego choroby. Mieszkanie osobno częściowo może zmniejszyć to obciążenie, gdyż w razie potrzeby pomocą partnerowi służyć będą jego dzieci lub specjaliści (Davidson, 2002).

\section{Uwarunkowania pragnienia posiadania partnera w okresie późnej dorosłości}

Niewątpliwie posiadanie partnera życiowego może pozytywnie oddziaływać na dobrostan psychiczny jednostki. Tworzenie bliskiej więzi interpersonalnej pozwala na zaspokojenie potrzeby przynależności (Leary i Baumeister, 1995), zmniejszając poczucie osamotnienia, oraz daje poczucie bezpieczeństwa, a także zwiększa prawdopodobieństwo otrzymania opieki i wzajemnego wsparcia w chorobie (Buss, 1990). Jednak oczywiste jest, że pomimo istniejących korzyści nie każda osoba owdowiała decyduje się na wejście w nowy związek. Powstaje pytanie, jakie czynniki sprawiają, że wdowy i wdowcy wyrażają pragnienie zaangażowania się w romantyczną relację. Chęć wejścia w nowy związek romantyczny może być motywowana wieloma zmiennymi natury psychologicznej i biologicznej oraz związanymi z nimi czynnikami socjoekonomicznymi.

Jednym z powtarzających się w pracach czynników mogących oddziaływać na angażowanie się w romantyczne relacje jest idealizacja zmarłego współmałżonka (Kleszcz-Szczyrba, 2012; Bennet, Arnott i Soulsby, 2013; Znaniecki-Lopata, 1981). Renata Kleszcz-Szczyrba (2012) w pracy Uwarunkowania zmiany w autoportrecie psychologicznym kobiet po stracie współmałżonka zwróciła uwagę na tendencję badanych wdów do zawyżania oceny jakości związku sprzed śmierci męża. Zjawisko to tłumaczyła brakiem przyzwolenia w polskiej kulturze na negatywne wypowiedzi dotyczące zmarłych, mogącym prowadzić do powstania nowego wyidealizowanego i pozbawionego skaz obrazu partnera. Z kolei Helena Znaniecki-Lopata (1981) opisała konstrukt sanktyfikacji zmarłego męża (ang. husband sanctification), który dotyczy tendencji do silnego idealizowania nieżyjącego współmałżonka oraz wspólnego życia sprzed jego choroby lub śmierci. Sanktyfikacja miała ułatwiać przejście przez proces adaptacji do wdowieństwa. Rekonstrukcja posiadanej reprezentacji zmarłego męża sprawiała, że zostawał on wyniesiony na pozycję „odległego, rozumiejącego obserwatora z zaświatów”, a w pamięci wdowy pozostawały głównie przyjemne wspomnienia. Pozwalało to także na poradzenie sobie z negatywnymi 
odczuciami na swój temat i podniesieniem poczucia własnej wartości w trakcie procesu żałoby. W badaniach wykazano dodatni związek sanktyfikacji męża z oceną roli żony jako najważniejszej w życiu kobiety. Dodatkowo wykazano negatywny związek sanktyfikacji z poziomem edukacji - dłuższy okres kształcenia się był związany z niższą tendencją do sanktyfikacji. Znaniecki-Lopata sądziła, że pragnienie zaangażowania się w nowy związek może być związane z idealizacją zmarłego męża w taki sposób, że żaden potencjalny nowy partner nie będzie w stanie (w oczach wdowy) dorównać poprzedniemu mężowi. Koncept oddziaływania sanktyfikacji na intencję ponownego wejścia w związek lub zawarcia małżeństwa badali też Bennett i in. (2013) - badacze skoncentrowali się na grupie wdowców, analizując na terenie Wielkiej Brytanii wywiady z sześćdziesięcioma mężczyznami. Wyniki badań potwierdziły, że mężczyźni również przejawiają tendencję do sanktyfikacji zmarłej partnerki. Wywnioskowano, że odczuwana przez wdowców niepewność co do ponownego ożenku może być powodowana sanktyfikacją zmarłej żony. Osoby badane przejawiały niepokój o to, czy kolejne małżeństwo będzie równie udane co pierwsze. Natomiast u wdowców, którzy otwarcie wyrażali swoje intencje dotyczące ponownych związków, sanktyfikacja nie odgrywała żadnej roli.

Badania na temat pragnienia zaangażowania się w nowe związki wśród wdów przeprowadziła także Sara M. Moorman, Alan Booth i Karen L. Fingerman (2006). W pracy sprawdzono następujące zmienne, które mogły stanowić predyktory: wiek, status socjoekonomiczny, otrzymywane wsparcie społeczne oraz zdrowie fizyczne i psychiczne. Wyniki badania wykazały, że młodszy wiek, silniejsze poczucie smutku oraz wyższy poziom lęku stanowiły istotne predyktory zainteresowania wdów powtórnym zamążpójściem.

Obszerne badania zostały zrealizowane w 1998 r. przez Marię M. Talbott wśród 64 wdów powyżej 60. roku życia. Badaczka postawiła dziesięć hipotez, sprawdzając związek chęci zaangażowania się w ponowny związek z mężczyzną a wybranymi czynnikami psychologicznymi i socjodemograficznymi. Warto nadmienić, że $66 \%$ osób badanych wyraziło zainteresowanie płcią przeciwną, ale tylko 15\% pozytywnie wypowiadało się na temat ponownego zamążpójścia. Zgodnie z przedstawionymi hipotezami przebadano korelację z następującymi zmiennymi: (1) liczbą zawartych małżeństw i długością trwania związku, (2) wiekiem wdowy, (3) odczuwaną satysfakcją z małżeństwa, (4) mobilnością wdowy (posiadaniem prawa jazdy), (5) silniejszym przeżywaniem żałoby i wykazywaniem objawów depresyjnych po śmieci męża, (6) aktywnością zawodową, (7) izolacją społeczną, (8) stabilnością finansową, (9) zdrowiem fizycznym, (10) sprawowaniem opieki nad chorym 
mężem do czasu jego śmierci. Analizy wykazały, że istnieje dodatni związek pomiędzy zainteresowaniem ponownym związkiem z mężczyzną/zamążpójściem a: (1) liczbą małżeństw, (2) odczuwaną satysfakcją z małżeństwa, (3) aktywnością zawodową oraz (4) lepszym stanem zdrowia. Natomiast korelacja negatywna występowała ze zmiennymi: (1) długość trwania związku - im dłuższy był czas trwania związku, tym mniejsze zainteresowanie powtórnym związkiem wykazywały wdowy, co Talbott tłumaczyła wyższym poziomem odczuwalnej więzi ze zmarłym, a także (2) wiek wdowy młodsze seniorki przejawiały wyższe zainteresowanie zaangażowaniem w romantyczne relacje.

Powyższy przegląd literatury wskazuje, że angażowanie się w nowe związki romantyczne przez wdowy jest zjawiskiem złożonym. Badacze wyróżniają czynniki, które można przypisać do trzech kategorii: (1) zmienne psychologiczne - np. poziom lęku, tendencja do sanktyfikacji, (2) czynniki biologiczne - wiek oraz stan zdrowia, a także (3) okoliczności zewnętrzne np. sytuacja socjoekonomiczna czy dostępność do potencjalnych partnerów.

\section{Podsumowanie}

Niniejszy artykuł pisany był na początku roku 2021, gdy w Polsce nadal trwała epidemia wirusa COVID-19. Biorąc pod uwagę dane wskazujące na to, że osoby owdowiałe są bardziej narażone na poczucie osamotnienia (Zych, 2010) i że od roku, szczególnie seniorom, zalecana jest izolacja społeczna, temat bliskich i intymnych relacji wśród wdów i wdowców wydaje się tym bardziej istotny. Funkcjonujące w przestrzeni publicznej stereotypy odbierające osobom powyżej 60. roku życia poczucie atrakcyjności i negujące ich seksualność mogą prowadzić do internalizacji szkodliwych przekonań seniorów na temat siebie (Butler, 2005). Tymczasem osoby w okresie późnej dorosłości przeżywają miłość romantyczną w taki sam sposób jak osoby młodsze (Wang i Nguyen, 2010) i czerpią wiele korzyści dzięki wsparciu życiowego partnera (Carr, 2004).

Omawiane w niniejszym artykule badania mają swoje ograniczenia i nie dają jednoznacznej odpowiedzi na pytanie o charakterystykę związków w okresie późnej dorosłości oraz uwarunkowania pragnienia posiadania partnera u osób owdowiałych. Opisywana problematyka jest złożona, a przywoływane dane stanowią pewne uogólnienie, nieuwzględniające indywidualnych przypadków. Dodatkową trudność może stanowić generalizacja wyników na polską populację, gdyż w polskiej literaturze istnieje 
niewiele badań dotyczących powtórnych związków osób owdowiałych w okresie późnej dorosłości. Dlatego celem pośrednim tego artykułu było uzupełnienie pewnej istniejącej luki oraz zainspirowanie innych naukowców do podjęcia badań w tym obszarze tematycznym, gdyż pozwoli to na jeszcze lepsze zrozumienie trudności, z jakimi mogą się zmagać wdowy i wdowcy, którzy pragną nawiązać nową romantyczną relację.

\section{Literatura}

Bee, H. (1998). Psychologia rozwoju człowieka. Poznań: Zysk i S-ka Wydawnictwo.

Bennet, K.M., Arnott, L., Soulsby, L.K. (2013). You're not getting married for the moon and the stars: The uncertainties of older British widowers about the idea of new romantic relationships. Journal of Aging Studies, 27, 499-506.

Bielan, Z., Stanowska, I. (2014). Funkcjonowanie seksualne kobiety dojrzałej w okresie poprokreacyjnym. W: Z. Lew-Starowicz, K. Waszyńska (red.), Przemiany seksualności w społeczeństwie współczesnym. Poznań: Wydawnictwo Naukowe UAM.

Borell, K., Ghazanfareeon Karlsson, S. (2007). Reconceptualizing intimacy and ageing: Living apart together. W: S. Arber, J. Ginn (red.), Gender and Ageing: Changing Roles and Relationships. Maidenhead: Open University Press.

Brzezińska, A.I., Trempała, J. (2003). Wprowadzenie do psychologii rozwoju. W: J. Strelau (red.), Psychologia. Podręcznik akademicki. Gdańsk: Gdańskie Wydawnictwo Psychologiczne.

Buss, D.M. (1990). The evolution of anxiety and social exclusion. Journal of Social and Clinical Psychology, 9, 196-210.

Butler, R.N. (2005). Ageism: Looking back over my shoulder. Generations, 3, 84-86.

Carr, D. (2004). The desire to date and remarry among older widows and widowers. Journal of Marriage and Family, 66, 1051-1068. https://doi.org/10.1111/j.00222445.2004.00078.x.

Coverman, S., Sheley, J.F. (1986). Changes in men's housework and child-care time. Journal of Marriage and the Family, 48, 413-422.

Davidson, K. (2002). Gender differences in new partnership choices and constraints for older widows and widowers. Ageing International, 27, 43-60.

Evenson, K.R. i in., The effects of widowhood on physical and mental health, health behaviors, and health outcomes: The women's health initiative. Health Psychology, 22(5), 513-522.

Grabowska, M. (2007). Stereotypy płci we wczesnej dorosłości. Bydgoszcz: Wydawnictwo UKW.

Hatfield, E., Sprecher, S. (1986). Measuring passionate love in intimate relations. Journal of Adolescence, 9, 383-410.

Hatfield, E., Walster, G.W. (1978). A New Look at Love. Boston: University Press of America. Havighurst, R. (1972). Developmental Tasks and Education. New York: McKay. 
Holmes, T.H., Rahe, R.H. (1967). The Social Readjustment Rating Scale. Journal of Psychosomatic Research, 11(2), 213-218. https://doi.org/10.1016/0022-3999(67)90010-4.

Kaleta, K.P., Jaśkiewicz, A. (2007). Szanse rozwoju w okresie późnej dorosłości. Warszawa: Uniwersytet Warszawski - Wydział Psychologii.

Karlsson, S.G., Borell, K. (2002). Intimacy and autonomy, gender and ageing: Living apart together. Ageing International, 27(4), 11-26. https://doi.org/10.1007/s12126002-1012-2.

Karlsson, S.G., Borell, K. (2005). A home of their own: Women's boundary work in LAT Relationships. Journal of Aging Studies, 19, 73-84. https://doi.org/10.1016/j.jaging.2004.03.008.

Kielar-Turska, M. (2002). Rozwój człowieka w pełnym cyklu życia. W: J. Strelau (red.), Psychologia, podręcznik akademicki (ss. 324-327). Gdańsk: Gdańskie Wydawnictwo Psychologiczne.

Kleiber, M. (2008). Memoriał Komitetu Prognoz „Polska 2000 Plus” przy Prezydium PAN dla najwyższych władz Rzeczypospolitej Polskiej w sprawie programu działań na rzecz poprawy sytuacji ludzi w starszym wieku. Warszawa.

Kleszcz-Szczyrba, R. (2012). Uwarunkowania zmiany w autoportrecie psychologicznym kobiet po stracie współmałżonka. Przegląd Psychologiczny, 55(1), 41-57.

Leary, M., Baumeister, R. (1995). The need to belong: Desire for interpersonal attachment as a fundamental human motivation. Psychological Bulletin, 117(4), 497-529. https:// doi.org/10.1037/0033-2909.117.3.497

Levinson, D.J. (1978). The Seasons of Man's Life. New York: Oxford University Press.

Malta, S. (2013). Love, Sex and Intimacy in New Late-life Romantic Relationships. Melbourne: Swinburne University of Technology.

Moorman, S.M., Booth, A., Fingerman, K.L. (2006). Women's romantic relationships after widowhood. Journal of Family Issues, 27, 1281-1304. https://doi. org/10.1177/0192513X06289096.

Niewiedział, D. (2014). Wybrane psychospołeczne predyktory procesu adaptacji do wdowieństwa starzejących się kobiet. Styl „odwiązania” od partnera. Rocznik Lubuski, 40(1), 59-72.

Pikuła, N.G. (2016). Poczucie sensu życia osób starszych. Inspiracje do edukacji w starości. Kraków: Impuls.

Przetacznik-Gierowska, M., Tyszkowa, M. (2006). Psychologia rozwoju człowieka. Zagadnienia ogólne. Warszawa: Wydawnictwo Naukowe PWN.

Stańczak, J., Marzec, D. (2013). Stan i struktura demograficzna ludności. W: L. Nowak (red.), Ludność. Stan i struktura demograficzno-społeczna. Narodowy Spis Powszechny Ludności i Mieszkań 2011. Warszawa: Zakład Wydawnictw Statystycznych.

Steuden, S. (2020). Psychologia starzenia się i starości. Warszawa: Wydawnictwo Naukowe PWN.

Straś-Romanowska, M. (2001). I Konferencja Psychologów Life-Span: między psychologią rozwojową a psychologią rozwoju. Przegląd Psychologiczny, 44(1), 93-103.

Sullivan, A.R., Fenelon, A. (2014). Patterns of widowhood mortality. Journals of Gerontology, Series B: Psychological Sciences and Social Sciences, 69(1), 53-62, https:// doi.org/10.1093/geronb/gbt079. 
Szinovacz, M., Harpster, P. (1994). Couples’ employment/retirement status and the division of household tasks. Journal of Gerontology: Social Sciences, 49, 125-136.

Szukalski, P. (2006). Wdowieństwo w starszym wieku w Polsce. Gerontologia Polska, 14(2), 63-70.

Szukalski, P. (2013). Małżeństwo. Poczq̨tek i koniec. Łódź: Wydawnictwo Uniwersytetu Łódzkiego.

Szukalski, P. (2015). Małżeństwa w Polsce w ostatnich dekadach. Demografia i Gerontologia Społeczna - Biuletyn Informacyjny, 5, 1-4.

Szukalski, P. (2016). Owdowienia we współczesnej Polsce. Demografia i Gerontologia Społeczna - Biuletyn Informacyjny, 9, 1-4.

Tedeschi, R.G., Park, L.C. Calhoun, L.G. (1998). Posttraumatic Growth. Positive changes in the Aftermatch of Crisis. Malwah: Erlbaum.

Talbott, M.M. (1998). Older widows' attitudes towards men and remarriage. Journal of Aging Studies, 12(4), 429-449. https://doi.org/10.1016/S0890-4065(98)90028-7.

Trafiałek, E. (2003). Polska starość w dobie przemian. Katowice: Wydawnictwo UŚ.

Wang, A.Y., Nguyen, H.T. (1995). Passionate love and anxiety: A cross-generational study. The Journal of Social Psychology, 135(4), 459-470. https://doi.org/10.1080/00224 545.1995.9712215.

Zawadzka, D., Stalmach, M. (2015). Problemy psychologiczne osób w okresie starości. Cz. I. Najważniejsze wyzwania i trudności. Hygeia Public Health, 50(2), 298-304.

Zettel, L.A., Rook, K.S. (2004). Substitution and compensation in the social networks of older widowed women. Psychology and Aging, 19(3), 433-443. https://doi. org/10.1037/0882-7974.19.3.433.

Znaniecki-Lopata, H. (1981). Widowhood and husband sanctification. Journal of Marriage and Family, 43(2), 439-450.

Zych A.A. (2010). Leksykon gerontologii. Kraków: Impuls. 